\title{
Dansk og tysk Historieforskning og Historieskrivning efter Krigen vedrørende Sønderjylland.
}

Af Frode Gribsvad.

Sønderjydske Aarbøger har tidligere bragt Oversigter over historisk Litteratur vedrørende Sønderjylland. Saadanne Oversigter vil Aarbøgerne i den kommende Tid atter bringe, da der i deres Læsekreds findes Ønske herom. Som en Indledning til disse Oversigter skal der her gives en kort Redegørelse for dansk og især tysk Historieskrivning efter Krigen vedrørende Hertugdømmerne, sammenlignet med den tidligere, da den $\mathrm{i}$ mange Henseender viser et andet Billede end for.

I Tiden fra Nationalitetskampens Opstaaen med Uwe Jens Lornsens Optræden i 1830 indtil 1864 var den Litteratur vedrørende Sønderjyllands Historie, der fremkom saavel fra dansk som fra tysk Side, i høj Grad præget af Kampen. Den var ensidig, oftest. tillige polemisk. Selv Varker som Allens "Det danske Sprogs Historie i Hertugdømmet Slesvig eller Sønderjylland " og Georg Waitz' "Schleswig-Holsteins Geschichte» er meget ensidige og partiske. Med 1864 sker der en Forandring med Hensyn til sønderjydsk Historieforskning. Fra tysk Side tabte man forbavsende hurtigt Interessen for Sønderjyllands Historie. Det havde jo ikke længere praktisk Interesse at beskæftige sig hermed, nu da det politiske Spørgsmaal var afgjort. 1833 var Gesellschaft für schleswig-holsteinische Geschichte bleven stiftet. Det havde ud- 
givet forskellige Tidsskrifter, fra $1870 » Z e i t s c h r i f t$ der Gesellschaft für Schleswig-Holsteinische Geschichte«, men dets Afhandlinger indtil Aarhundredskiftet vedrørte væsentligst holstenske Forhold, kun meget lidt nordslesvigske.

Anderledes forholdt det sig med de danske Historikere. Dansk Historieforskning og Historieskrivning fik en Blomstringstid i den sidste Trediedel af det 19. Aarhundrede, og det var saa langtfra, at de danske Historikere tabte Interessen for Sønderjyllands Historie, at det tværtimod kun er faa af dem, der ikke har taget et eller andet Spørgsmaal af den op til Behandling. Men paa en helt anden Maade end tidligere. A. D. Jørgensen gik i spidsen her. 1864 gav ham Indvietsen til hans Historikergerning. Han blev klar over, at man maatte se den haarde Virkelighed $\mathrm{i} \emptyset$ jnene, og han begyndte at undersøge Grunden til Danmarks Ulykke. Erlighed, Redelighed, Virkelighedssyn blev da det Krav, som Nederlaget 1864 stillede danske Historikere i deres Forskning, som det stillede hele det danske Folk det $\mathbf{i}$ al dets Virken. Men det gjorde ogsaa, at den Del af det danske Folks Historie, som angik Sønderjylland, maatte tages op til fornyet Undersogelse og kritisk Prøvelse. Det var ikke længere Opgaven polemisk at hævile, at Danmark havile Ret, nej, snarere for vor egen Skyld at klarlægge, hvor Danmark havde fejlet, og det gjaldt om saa vidt muligt at forstaa Modstanderen, at man ikke skulde undervurdere ham. Man havde Fornemmelsen af, at man delvis havde levet paa et Blændværk, derfor var Ulykken kommen over os; man matte se den haarde Virkelighed $i$ Øjnene for at kunne rejse sig igen. "Det forekom mig, at vi alle tilhobe var en slægt af blød- 
agtige drømmere, uden kraft og marv, og at vi forst og fremmest trængte til at hærdes«, siger A. D. Jørgensen ${ }^{1}$ ). Man kunde da ikke slaa sig til Ro med den foregaaende Tids Resultater, heller ikke historiske Resultater, spørgsmaalene maatte tages op til fornyet Undersøgelse, og der fremstod saaledes i Danmark en ny sønderjydsk Historieforskning, grundig, videnskabelig, med Forsag paa at forstaa Modstandernes Synspunkter og Forudsætninger. Det ligger udenfor denne Artikels Omraade at komme niernere ind paa, hvad der her er ydet i det halve Aarhundrede 1864-1914. Der skal blot peges paa A. D. Jorgensens Artikel i Dansk Biografisk Lexikon om Hertug Christian August af Augustenborg, hvor han bedommes ganske anderledes, end han tidligere var bleven det i Danmark, eller paa hans Skildring af det 19. Aarhundredes Historie i 6. Bind af Danmarks Riges Historie, eller Kr. Erslevs Undersøgelser af Arvehyldingsakterne 1721, hvor Aktstykkerne læses uden forudfattet Mening og søges forstaaet ud fra Datidens Synspunkter. Blot disse Eksempler viscr, hvor uafhængig af tidligere Tiders Synspunkter danske Historikere tog Sønderjyllands Historie op til Behandling. Hele Tiden, i hvert Fald indtil Verdenskrigen, har da ogsaa danske Historikere været forende i Forskningen af sonderjyllands Historie. Saa meget mærkeligere var det, at man fra tysk Side i lang Tid kun med ringe Opmærksomhed fulgte det Arbejde, danske Historikere her ydede. Ogsaa det er et Tegn paa, hvor ringe Interesse der nu var for Sunderjyllands - for den Sags skyld ogsaa Holstens

1) En redegorelse for min udvikling og mit forfatterskab. S. 112. 
- Historie i Tyskland. Medens inden 1864 store tyske Historikere som Waitz havde taget Hertugdømmernes Historie op til Undersøgelse, blev man nu staaende ved de Resultater, man da var kommen til. Man var bestandig kun daarligt i Stand til at have sig op over den Ensidighed, som prægede Kamptiden. Saaledes udgav den i 1929 afdøde August Sach 1896-1907 sin Bog »Das Herzogtum Schleswig in seiner ethnographischen und nationalen Entwickelung«, vel et af de betydeligste Arbejder, der i den Tid er ydet fra tysk Side, ogsaa indeholdende meget værdifuldt, men dog i Henseende til Ensidighed nærmest at sammenligne med f. Eks. Allens "Det danske Sprogs Historie« fra et halvt Aarhundrede tidligere. Forbavsende ogsaa at se, hvor længe man fra tysk Side mente at kunne beskæftige sig med Hertugdømmernes Historie uden at kunne Dansk og uden at tage Hensyn til, hvad dansk Historieforskning havde ydet. Følgen blev da ogsaa, at der Gang paa Gang blev begaaet Fejl, som vilde have været undgaaet, hvis man havde fulgt med i den danske Historieforskning.

Omkring Aarhundredskiftet begyndte man dog at indse, at det ikke længere kunde gaa ikke at tage Hensyn til den danske Historieforskning. Det var især 2 Mænd, der havde deres Opmærksomhed henvendt lerpaa, og som arbejdede paa at skabe en vidcre Horisont for den tyske Forskning af Hertugdømmernes Historie. Den ene var Landesbibliotekar Rudolph v. Fis ch e r-Benzon i Kiel. Han var fodt 1839 i Westermühlen ved Rendsborg, studerede Naturvidenskab og var 1869-92 Lærer ved forskellige lærde Skoler, sidst i Kiel fra 1878. Men forst efter at han 53 Aar gammel af Helbredshensyn 
havde taget sin Afsked, faldt hans egentlige Livsgerning. Fra 1895 til sin Død 1911 var v. FischerBenzon Leder af det Bibliotek, som Provinsen havde grundlagt i Kiel, og som 1899 fik Navnet "SchleswigHolsteinische Landesbibliotek «. Fra 1898 var han tillige Sekretær i Gesellschaft für Schleswig-Holsteinische Geschichte. Han var, som vi har set, ikke Historiker af Fag, men efter at han havde overtaget Ledelsen af Landesbibliotek, blev Hertugdømmernes Historie hans store Interesse. Ved Biblioteket fik han samlet en meget stor Litteratur vedrørende Hertugdømmernes Historie, ogsaa - og det ikke mindst - den danske Litteratur herom. Ved at blade Landesbiblioteks Kataloger igennem vil man faa et Indtryk af, hvilket værdifuldt Hjælpemiddel til Studiet af Hertugdømmernes Historie man i Kiel har i dette, og Aren herfor tilkommer forst og fremmest v. Fischer-Benzon. Men ogsaa i Gesellschaft für Schleswig-Holsteinische Geschichte fik han stor Betydning. Han var den egentlige Pedaktør af Zeitschrift, hvis aarlige Bind efterhaanden voksede i Omfang og ogsaa i Lødighed. Især maa nævnes de Litteraturoversigter, der udarbejdede af v. Fischer-Benzon selv nu fremkom i Tidsskriftet. De er meget fyldige, og oplyscnde Noter er knyttet til dem. De betyder et værdifuldt Hjælpemiddel for alle, der beskæftiger sig med Hertugdømmernes Historie, og ikke mindst ad denne Vej har v. Fischer-Benzon gjort opmærksom paa den danske Litteratur herom.

Den anden Mand, der har arbejdet paa at abne sine Landsmænds Øjne for den danske Historieforskning vedrørende Sønderjylland er Godsejer Pa $\mathbf{l}$ von Hedemann-He espen fra Deutsch Nienhof 
i Holsten. Han er heller ikke Historiker af Fag, men Hertugdømmernes Historie har altid haft hans Interesse, og hans Forbindelse med Prof. v. FischerBenzon nærede den yderligere. 1913 traadte han ind i Gesellschaft's Bestyrelse og leverede i de følgende Aar Litteraturoversigterne og en Del længere Anmeldelser af historisk Litteratur. Men ogsaa herudover var han i disse Aar en flittig Medarbejder ved Zeitschrift. Han har udarbejdet Registre til Die Schleswig - Holsteinischen Anzeigen $1750-1800$ (i Bd. 41 og 45) og tilalleslesvigholstenske Tidsskrifter og Samlinger ef ter 1750 (i Bd. 45) og Indholdsfortegnelsetilen Del lokalhistoriske og biograf i s k e Værker (i Bd. 49), fortræffelige Hjælpemidler for alle, der beskæftiger sig med Hertugdønmernes Historie. Ogsaa andre Bidrag fra hans Haand bragte Zeitschrift i disse Aar, nævnes kan "E i Gang durch das Gewerbe unserer vergangenheit« (Bd. 48, 1918) og $" D$ ie politischen Grundzüge in der Geschichteder holsteinischen Verwaltung (Bd. 49). Med dette Bind forsvinder v. Hedemann-Heespen som Zeitschrifts Medarbejuler, og 1922 traadte han ud af Gesellschafts Bestyrelse. Det er ingen Hemmelighed, at dette skyldes et Brud. For Zeitschrift betyder det et Tab, at det har mistet sin ejendommeligste, mest sxrprægede Medarbejcler. Fra da af træffes v. Hedemann-Heespen som Medarbejder ved det i 1923 oprettede nye Tidsskrift "Nordelbingen". Ogsaa Schleswig-Holsteinischer Kunstkalender har bragt Afhandlinger fra hans Haand som $m \mathrm{~K} u l t u r$ u d Adel in Schleswig - Holstein während des 1 8. Jahrhunderts" (1912) og "( ther den 
Adel in Nordschleswig« (1920). Men hans Hovedværk, det Værk, hvori han har nedlagt Resultatet af sine omfattende Studier af Hertugdømmernes politiske, men især indre og kulturelle Historie og sammenfattet det under sit ejendommelige Helhedssyn, er det bindstærke Værk $» D$ i e $H$ erzog t ü m e r Schleswig - Holstein und die Neuzeit" (1926), der senere skal omtales. v. Hedemann-Heespen er vel den Mand indenfor den tyske slesvig-holstenske Historieforskning, der stærkest har haft Blikket vendt imod dansk Historieforskning og Historieskrivning - dette betyder langtfra, at man fra dansk Side altid har kunnet være enig med ham i hans Synspunkter - men man har, efter at han har udsendt sit Hovedværk, anerkendt hans Betydning ogsaa for dansk Historie ved at optage ham som Medlem af "Danske Selskab«, som han selv siger: det første slesvig-holstenske Medlem siden 1864.

Vi har set, hvorledes v. Fischer-Benzon og v. Hedemann-Heespen henledede Opmærksomheden paa den danske Forskning vedrørende Hertugdømmernes Historie, men endnu var der fra tysk Side intet Værk fremkommet, der kritisk videnskabeligt tog Hertugdømmernes Historie op til Undersøgelse. Det første Værk, der tog et Afsnit heraf op til ny Behandling, udkom i 1916. Det var ikke skrevet af en Mand fra Hertugdømmerne, og det kom ikke fra Kiel. Det var Johannes Brocks $\gg D i e$ Vorgeschichte der schleswig-holsteinischen Erhebung vor 1848«. Forfatteren, der, da Bogen udkom, var død, falden i Krigen - han var gaaet med som Frivillig - var en ganske ung Mand, født 1887 i Gøttingen. Han var en ideelt anlagt Natur, kunst- og 
sportsinteresseret, deltog i »Wandervögel-Bevægelsen“, studerede Filosofl, Pædagogik, germansk Filologi, Statsvidenskab og Geografl, men især Historie, som han fra 1910 samlede sig om og studerede i Gøttingen under den demokratiske Professor Max Lehmann (død 1929). Denne gjorde Brock opmærksom paa, at det dansk-tyske Spørgsmaals Historie forud for 1848 maatte tages op fra tysk Side til ny Behandling, saaledes at man drog de Resultater, man var kommen til fra dansk Side, med ind i Undersøgelsen og vurderede dem. Da Brock ønskede at udarbejde en Doktorafhandling, valgte han dette Emne, og de forste Kapitler af Bogen bragte ham da ogsaa Doktorgraden først paa Aaret 1913. Derefter gjorde han Bogen færdig og tænkte paa at foretage en Studierejse til de forenede Stater og Kanada, da Verdenskrigen udbrød, og han meldte sig som Frivillig. I Efteraaret 1915 faldt han paa Østfronten.

Bogen, der i 1918 blev oversat paa Dansk af Bibliotekar Raphael Meyer, men først udgivet 1927, har for Danske nok saa stor Interesse som det første Tegn paa en anden Indstilling fra tysk Side end den, vi tidligere kendte, som ved at bringe nyt Stof frem. Forfatteren har meget dygtigt udnyttet de trykte Kilder, baade fra dansk og fra tysk Side, men har kun i ringe Grad brugt utrykt Materiale. Bogen er skrevet ud fra et nationalt, demokratisk Standpunkt. Den slesvigholstenske Bevægelse ses i Sammenhæng med de tilsvarende Enheds- og Frihedsbevægelser i Tyskland. Hans Sympati er paa den nationale Stats Side imod den dansk-tyske Helstat og paa det demokratiske, liberale Partis Side imod de Privilegerede. Bogen er skrevet af en Tysker med Sympati for den slesvigholstenske Bevægelse, men det nye er For- 
søget paa at behandle Emnet objektivt videnskabeligt og paa ogsaa at forstaa den danske Bevægelse. Med stor Dygtighed er Forfatteren i Løbet af kort Tid trængt ind $\mathrm{i}$ det for ham hidtil ukendte Stof. Dog kan det mærkes, at Bogen er et Begynderarbejde, og at Forfatteren i nogen Grad mangler længere Tids Indleven i Emnet. Man vil fra dansk Side ikke kunne godkende alle hans Synspunkter og heller ikke mange Enkeltheder, men man læser Bogen med stor Interesse og ogsaa med Udbytte. Det er dog et Spørgsmaal, om der var nogen Grund til at oversætte den paa Dansk. De fleste af dem, der vil kunne lære af den, vil sikkert kunne læse den paa Tysk. Noget andet er, at man savner en Undersøgelse fra dansk Side af Slesvigholstenismen og $i$ det hele taget en samlet Fremstilling af den dansk-tyske Strid 1830-48.

I Tiden 1864-1920 havde man altsaa fra tysk Side kun viet Hertugdømmernes, især da Sønderjyllands, Historie forholdsvis ringe Interesse og kun ydet lidt af større Betydning. Var der end $i$ den sidste Tid visse Tegn til, at der heri var ved at ske en Endring, saa var det dog endnu kun Tegn. 1920 med Nordslesvigs Afstaaelse til Danmark kom til at betyde en Endring heri. Siden da er der paa tysk Side vokset en levende Interesse for Hertugdømmernes Historie frem, og fortrinsvis for Nordslesvigs Historie. I nogen Grad har 1920 haft samme Betydning for tysk Historieforskning angaaende Hertugdømmerne, som 1864 havde for dansk Historieforskning. Med travl Iver har man kastet sig herover og har allerede udsendt en Mængde Arbejder, omfattende de forskelligste Emner. Langtfra alt har været betydningsfuldt eller kritisk videnskabeligt 
Arbejde, men ogsaa i len Henseende er der i det sidste Tiaar præsteret mere end i det foregaaende halve Hundrede Aar.

Centrum for den tyske Historieforskning vedrørende Hertugdømmerne er Kiel. Universitetet og dets Lærere er gaaet i spidsen. Her findes Landesbiblioteket med dets righoldige Litteratur, og hertil flyttedes i Vinteren 1922-23 det slesvig-holstenske Statsarkiv fra Slesvig, Institutioner, der i det forlobne Tiaar har ydet Studiet af Hertugdømmernes Historie megen Støtte. Her har Gesellschaft für Schleswig-Holsteinische Geschichte sit Sæde, og herfra udsendes dets Skrifter, og her blev det nye Schleswig-Holsteinische Universitätsgesellschaft dannet i Efteraaret 1923 og senere i Forbindelse hermed den Baltiske Kommission med det Baltiske historiske Forskningsinstitut.

Kiels Universitet, der har betydet saa meget i Kampen imellem Danske og Tyske, er nu blevet et af Hovedsæderne for den tyske Forskning af Hertugdømmernes Historie, især ved Professorerne Brandts og Scheels Virksomhed. Stærkere end fra noget andet Sted er herfra Kravet om en ny Indstilling, om større Objektivitet og om kritisk videnskabelig Forskning bleven stillet. Fra dansk Side har man straks været klar herover og har ikke ladet det mangle paa Anerkendelse herfor. Der er betydelig Forskel paa de to Professorers Personligheder, Forudsætninger og Synspunkter. Professor ot to Brandt kom til Kiel 1920 som Leder af det historiske Proseminarium ug blev 1924 udnævnt til overordentlig Professor i vesteuropæisk Historie, men da han i Oktober 1928 fik tilbudt en ordinær Professonstilling ved Universitetet i Erlangen, tog han derimod og forlod Kiel, 
hvilket man i hvert Fald fra dansk Side vil beklage, og som ogsaa blev beklaget fra en enkelt tysk Side v. Hedemann-Heespen og Schleswig-Holsteinische Landeszeitung, der bebrejdede Kiels Universitet, at man ikke havde søgt at beholde ham i Kiel. (Man har talt om en Rendsborg-Retning i Modsætning til Kiel.) Professor Brandt er hverken Slesviger eller Holstener, men Sydtysker, født i Heidelberg. Dette har vel givet ham en noget friere Indstilling til spørgsmaalene, men har ogsaa isoleret ham i Kiel, hvor han næppe følte sig hjemme. I de faa Aar, han var her, arbejdede han meget flittigt. Foruden at passe sin Lærergerning, som kan spores $\mathrm{i}$ den Interesse, han hos mange af sine Elever vakte for Problemer i Hertugdømmernes Historie, og i at han paapegede dem Opgaver f. Eks. som Emner for Doktorafhandlinger, naaede han at udsende flere historiske Værker, der har krævet et stort Arbejde og vidner om, at han i Løbet af den korte Tid i forbavsende Grad havde sat sig ind $i$ den danske Litteratur.

Brandts Hovedværk er "G e is tes le be n und Politik in Schleswig - Holstein um die Wende des 18. Jahrhunderts« (1925). I et indledende Kapitel skildres den danske Helstat $\mathbf{i}$ det 18. Aarhundrede. I Modsætning til Johs. Brock ser Brandt nærmest Idealet i A. P. Bernstoffs Helstat. Han roser Bernstoff, fordi han ikke krænkede Hertugdømmernes Ejendommeligheder eller Ridderskabets Privilegier. Dernæst giver han livfulde Karakteristikker af Fritz Reventlow og hans Hustru Julia fodt Schimmelmann paa Emkendorf i Holsten og den Kreds, der samledes om dem, konservativ, meget religiøs og paavirket af tysk Aandsliv. Han skildrer derefter denne Kreds' Kamp mod Rationalismen og 
Fritz Reventlow som Forer for Ridderskabet og dettes Kamp med Regeringen om sine Privilegier (Skattebevillingsretten) allerede i 1790'erne og Begyndelsen af det 19. Aarhundrede, hvorom man hidtil kun har vidst lidet. Dette Kapitel er derfor et af Bogens betydeligste og bringer os meget nyt. Han hævder, at der under denne Kamp opstod en bevidst tysk Nationalfølelse hos Fritz Reventlow, ligesom denne i Striden med Regeringen hævdede de gamle Stænderrettigheder af ideelle Grunde. Prof. Brandt har bragt en Del nyt Stof frem og $\mathrm{i}$ den velskrevne Bog givet et levende Billede af den Kreds, der samledes paa Emkendorf. Resultatet, han kommer til, er det interessante, at det ikke er Dahlmann, der er Ophavsmanden til Ridderskabets Kamp imod Regeringen, som begyndte allerede i 1790 'erne og efter en Standsning fornyedes 1813 før Dahlmanns Optræden, og at det heller ikke er Dahlmann, der først gjorde den slesvig-holstenske Privilegiestrid nationalpolitisk eller først vakte en tysk Nationalfølelse i Hertugdømmerne. Forf. vil føre alt dette tilbage til Fritz Reventlow og gøre Emkendorf til Slesvigholstenismens Vugge, ligesom han ogsaa lader Dahlmann være paavirket af Reventlow. Bogen, der ved Siden af v. Hedemann-Heespens store Værk maa regnes for det betydeligste, tysk Historieskrivning har at opvise fra disse Aar, er ikke forbleven uimodsagt. Fra dansk Side har Raadstuearkivar Axel Linvald givet en indgaaende Anmeldelse af den i Historisk Tidsskrift 9. R. IV. S. 76-91, anerkendende, men dog med adskillige Forbehold. I Zeitschrift Bd. 55 har Prof. Scheel anmeldt Bogen og skarpt angrebet det Resultat, Prof. Brandt er kommen til. Han indrømmer, at der paa Emkendorf fandtes en tysk Kulturfølelse, som kan 
kaldes Nationalfølelse, men en saadan tysk KulturNationalfølelse fandtes der lige fra Elben til Nord for Ejderen, uafhængig af Emkendorf. "Saadan set gives der i Hertugdømmerne ikke een Kilde, hvoraf den mægtige Strøm er opstaaet, men mange Kilder og Bække«. Brandt tillægger Emkendorf en Betydning, som det ikke har haft. Et nationalt Maal, som Dahlmann saa det, en venden sig bort fra Danmark som Fædreland og venden sig hen til det tyske Fædreland, har Ridderskabets første Kamp ikke bragt. Brandt har vurderet det nationalt mere positivt, end det kan hævdes. Hvis man kun søger Forhistorien eller Rødderne til en stor Bevægelse saa langt tilbage, som de bestemmende Motiver og Kræfter tydeligt kan kendes i deres faste Omrids, rækker den slesvigholstenske Rejsnings Forhistorie kun til Dahlmann. Yderligere har Prof. Scheel i sin Skildring af den unge Dahlmann vist dennes Betydning for Slesvigholstenismens Opstaaen. Ogsaa Prof. Dr. Carl Petersen har i sin Skildring af Nic. Falck taget Afstand fra Prof. Brandts Resultat. Ligeledes Dr. $H$. Christern i Hansischen Geschichtsblätter 1925, medens andre som v. Hedemann-Heespen og Th. Kaftan o. fl. har givet Forf. sin Tilslutning. Prof. Brandt har svaret sine Angribere $\mathrm{i}$ " $\mathrm{Z}$ u r V orge s c h i c h t e der schleswig - holsteinischen Erhebu ng" (Einzelschriften zur Politik und Geschichte. Herausgegeben von Dr. Hans Roeseler. 16. Schrift. Berlin. 1927.) Han fastholder her sin Opfattelse og hævder, at Dahlmanns Betydning bestaar i, at han krævede den gamle Forfatning fornyet efter Tidens Krav. Dragningen til Tyskland fandtes kun i de højere Lag og her endda kun hos enkelte, den var for 
lidt udviklet og uden sikker Ledelse, indtil den i Dahlmann vandt, hvad den manglede.

I 1925 kom ogsaa Prof. Brandts "G es chich te Schleswig - Holsteins. Ein Grundriss", en kort Oversigt over Hertugdømmernes Historie. Den betyder et stort Fremskridt fremfor tidligere tyske Værker af lignende Art. Fyldige Litteraturlienvisninger foran hvert Afsnit viser stort Kendskab ogsaa til den danske Litteratur, selv om et eller andet Værk kan mangle. Forf. siger i Forordet, at det helt igennem har været hans Bestræbelse at fastholde streng Saglighed og en afvejet Dom, begge paa videnskabeligt Grundlag, og Bogen er ogsaa - om end ud fra et tysk Synspunkt - skrevet med større Objektivitet, end vi er vante til, men vi maa dog fra dansk Side - som det ogsaa er bleven gjort - anholde forskellige Udtalelser, som naar det i Forbindelse med Laurids Skaus Skamlingsbanketale siges, at Skriftdansk lige saa lidt var de nordslesvigske Bønders Modersmaal som Højtysk, eller naar det hævdes, at den prøjsiske Regerings Fejlgreb efter 1864 paa langt nær ikke kan sammenlignes med de ukloge Daniseringsbestræbelser imellem Krigene. Og naar Bogen ender med at kræve en Grænserevision, betaler Prof. Brandt hermed en Tribut til tyske Stemninger, som ogsaa her faar ham til at svigte det Formaal, som han ifølge Forordet har sat sig. Adskillige Smaafejl har indsneget sig i Bogen, ingen har mere smaaligt gjort opmærksom derpaa end Landesbiliotekar Dr. Pauls i Kiel i en lidet velvillig Anmeldelse i Zeitschrift Bd. 57, som foranledigede Prof. Brandt til at udsende en Imødegaaelse, der vidner om, hvilke skarpe Modsætninger der herskede indenfor Kiels Historikerkredse. Alligevel blev Bogen vel- 
villigt modtaget, allerede $1926 \mathrm{kom}$ den i 2 . Oplag, og samme Aar oversattes den til Dansk. Det maa dog siges, at selv om vi i høj Grad har Brug for en kortfattet Sønderjyllands Historie eller maaske bedre Sønderjyllands og Holstens Historie - Holsten har dog igennem Aarhundreder staaet i Forbindelse med Danmark, og Kendskabet til dets Historie er i Almindelighed for ringe - kan Prof. Brandts ikke tilfredsstille os, og vi maa haabe, at det inden længe maa lykkes fra dansk Side at fremskaffe et Sidestykke til Prof. Brandts Grundrids.

I Tilknytning til Grundridset har Prof. Brandt i 1928 sammen med Studienrat K a r l W ö lf l e i Hamborg udsendt et Billedatlas "Schleswig - $\mathrm{Hol}$ steins Geschichte und Leben in Karten u n d B i l d e r nu, indeholdende et omfattende Billedog Kortstof til Belysning af Historien, saavel den politiske som Kulturhistorien. Der kan rejses Indvendinger imod Enkeltheder - og der skal i den Henseende henvises til H. V. Clausens indgaaende Anmeldelse i "Hejmdal" for 5., 9. og 11. Marts $1929-$ men det maa anerkendes, at det er et meget smukt Værk, der levende belyser mange Sider af Historien og Livet i Hertugdømmerne.

Endnu en lille Bog har Prof. Brandt udsendt fra Kiel, "Heinrich Rantzau und seine Relationen an lie dänischenkönige. Eine Studie zur Geschichte des 16 . Jahrhunderts." (1927). Indledningen, en kort Skildring af Henrik Rantzau, er den interessanteste Del af Bogen, der forøvrigt indeholder en kortfattet Oversigt over Indholdet af hans mange Relationer til de danske Konger. Heraf læser man med størst Interesse den 
Del, der omhandler hans Forhold til de sønderjydske Hertuger og Forholdene i Hertugdømmerne.

Det var saaledes intet ringe Arbejde, Professor Brandt ydede i de faa Aar, han var i Kiel, og det maa beklages, hvis hans Arbejde med Hertugdømmernes Historie er ophørt med hans Bortrejse fra Kiel.

Den anden Mand ved Kiels Universitet, som er kommen til at betyde noget nyt med Hensyn til den tyske Historieforskning vedrørende Hertugdømmerne, er Professor Ot to Sch e el, i mangt og meget forskellig fra Prof. Brandt. Han er Nordslesviger, født i Tønder, og har derfor den Indlevethed i og Forstaaelse af Forholdene i Nordslesvig, som det giver at have levet sine Barneaar og forste Ungdomsaar her. Han er Nordslesvigeren, der kan gribes af sit snævreste Hjemlands Skæbne og lidenskabeligt tage Del deri, som han gjorde det paa tysk Side i Afstemningstiden. Men han er ogsaa Videnskabsmanden, der bøjer sig for Kravet om kritisk Objektivitet og Anerkendelse af Sandheden, som vi har set det hos Professoren i Kiel. Og han er Manden, der hævdede at ville kæmpe ridderligt og med blanke Vaaben med Modstanderen, da han valgtes til SchleswigHolsteiner Bund's Formand. Prof. Scheel har .i en Del Aar været Professor i Kirkehistorie i Tübingen og har her paabegyndt et større Værk om Luther. I 1923 modtog han Kaldelsen til Universitetet i Kiel som den første Professor her i "Landesgeschichte". Han har her i de første Aar taget ivrig Del saavel i videnskabelige Foreningers Arbejde - som Universitetsselskabet og det Baltiske historiske Forskningsinstitut, hvortil han er Ophavsmanden - som i politisk Arbejde. Han er mere konservativ end Prof. Brandt og har ikke haft saa vanskeligt som denne 
ved at finde sig til Rette i Kiel. Han er Tilhænger af en nærmere Forbindelse imellem Norden og Tyskland, saaledes som det gav sig Udslag i Planen om det nordisk-tyske Universitetsstævne i Kiel og i DeutschNordische Zeitschrift, af hvis forste Numre han stod. som Udgiver, men han synes baade i den Maade, hvorpaa han greb Planen om Universitetsstævnet an, og $i$ andre Ting ikke altid $i$ det praktiske at kunne vurdere Personer og Forhold rigtigt. Hidtil er det forholdsvis lidt, han har ydet af Bidrag til Hertugdømmernes Historie, optaget som han har været af politisk Arbejde og desuden i lang Tid syg.

I 1925 udkom "Der junge Dahlmann« (i Universitetsselskabets Aarbog og som selvstændigt Skrift). Han søger heri ved dybtgaaende Undersøgelser at udfinde, med hvilke Forudsætninger Dahlmann kom til Kiel, og skildrer paa Grundlag af hans Skrifter hans statslige og nationale Synspunkter i Kjelertiden. Han hævder i Modsætning til Brandt, at Dahlmann uafhængig af Fritz Reventlow, under Paavirkning af Tidsbegivenhederne bliver Ophavsmanden til den tysk-nationale Slesvigholstenisme. Det er ham, der drager Ordene "uund dat se bliven ewich tosamende ungedelt» frem af Akterne fra $\left.1460^{1}\right)$, og paa Grundlag af den Forbindelse, der har bestaaet imellem Slesvig og Holsten, fremsætter han

1) Rudolf Bülck har i et lille Skrift "Up ewig ungedeelt. Entstehungsgeschichte eines politischen Schlagworts" (Kiel. 19:8.) vist, hvorledes man efterhaanden mere og mere omformede Ribeprivilegiernes Udtryk for at finde et godt brugeligt, populært Slagord, indtil det fandtes i Aabenraa-Lægen Dr. A. W. Neubers Sang fra 1841 "Lied von Schlei", der slutter: "Se schölln tosammen blieben - op ewig ungedeelt«, hvis sidste Linie efter Sangerfesten i Ekernførde 1845 blev Slesvigholstenismens Slagord. Ordene er en Omformning af Ribeprivilegiernes Udtryk og rammer i hvert Fald noget ved Siden af dette. 
Kravet om et tysk Slesvig-Holsten i Forbindelse med det tyske Rige. "Das Allgemeine des urkundlichen Rechts" (d. v. s. de Rettigheder, han udleder af Akterne fra 1460, gjort tidsmæssige) bliver for ham Retten til et tysk Rigsland Slesvig-Holsten ${ }^{1}$ ), som han mener kan virkeliggøres, uden at den danske Helstat slaas i Stykker. Danskerne i Slesvig voldte ham intet Samvittighedsnag, da han hævdede, at Slesvig oprindelig havde været beboet af Tyske, hvilket ikke kan billiges, men er forstaaeligt, siger Prof. Scheel, "endnu i vore Dage er denne Sprogbrug jo ikke uddød."

Vi ser heraf, at Prof. Scheel bryder med en fra tyske Historikeres Side ret almindelig Underkendelse af Danskheden i Sønderjylland og dens Berettigelse. Dette kommer endnu tydeligere frem i et Foredrag "Nordschleswig im schleswig-holstein ischen Gedanken«, som Prof. Scheel i August 1926 holdt i Kiel i Gesamtverein der Deutschen Geschichts- und Altertumsvereine, og som er trykt i "Nordelbingen« Bd. 5. Han hævder her, at man ikke kan tale om en oprindelig tysk Bebyggelse af Hertugdømmet Slesvig. Den ældste Befolkning var hverken dansk eller tysk. Danskerne er "nachweisbar « først fra det 5. Aarh. trængt langsomt ind i Landet, og det tyske Folk er først bleven til i det 9. og 10. Aarh. Den oprindelige Befolkning i Sønderjylland var "Vestgermaner", ikke Tyskere, men en Del af den Stamme, hvoraf Tyskerne siden har dannet sig. Med dem, der blev tilbage ved Udvandringen til England, blandede de fremtrængende Danske sig,

1) Salaleles ifolge scheel. Brandt forstadr Toltryket som de almindelige Frihedsgrundsætninger, Ribeprivilegierne indeholder, omformet efter Tidens Krav. (Zur Vorgeschichte der schleswig-holsteinische Erhebung. S. 38 ff.) 
ved Slien kom siden ogsaa en svensk Indvandring. Hvad der end maaske kan indvendes imod dette Synspunkt, det er i hvert Fald et andet, mere objektivt end det psevdovidenskabelige, vi som Regel har mødt fra tysk Side. Han vender sig ogsaa imod den Paastand, at det Sprog, der tales i Nordslesvig, ikke er Dansk. "Undertiden hører man jo, at den brede Masse i Nordslesvig slet ikke taler Dansk, dens Dialekt er overhovedet ikke en dansk, men en halvt vestgermansk Dialekt. Paa os, der har talt denne Dialekt fra vor Barndom af, gør denne Opdagelse et noget ejendommeligt Indtryk." Det kan være. rigtigt, at en Københavner ikke straks forstaar Omgangssproget i en Gestlandsby, men saaledes vilde ogsaa en Slesvigholstener, der kom til Ammertal, kunne tro, at der blev talt Hunnisk der. Uden Tvivl har vi i Nordslesvig med en i alt væsentlig "nordgermanisk" Dialekt at gøre. Han gør opmærksom paa, at Christian Paulsen og Christian Flor, Dahlmann og Falck samtidig virkede i Kiel. "I samme Hus, under det samme Tag bliver den nye slesvigholstenske Idé og den nye danske nationalpolitiske Opfattelse af Hertugdømmet Slesvig foredraget." Man kan, siger Prof. Scheel, være overrasket over, at en Historiker kunde gøre Forsøg paa at udbrede en anden Rets. betragtning over Hertugdømmet Slesvig end Dahlmanns og Falcks. Men man maa ikke glemme, at man i Danmark saa anderledes paa Begivenhederne 1721, at der blev talt Dansk i Slesvig, og at der gjaldt en anden Ret i Slesvig end i Holsten. Dertil kom fremfor alt det efterhaanden vakte danske Liv iblandt Nordslesvigs Smaaborgere og Smaabønder. Nissen, Koch og Fischer har vist sig mægtigere end den i Aand dem langt overragende Dahlmann, mæg- 
tigere ogsaa end den lidenskabelige Uwe Jens Lornsen, thi de har gjort Nordslesvig fremmed for Slesvig-Holsten.

Dette Foredrag er det tydeligste Eksempel paa den nye Indstilling overfor Sønderjyllands Historie, vi nu kan møde hos tyske Historikere, et Forsøg paa at forstaa det danske Synspunkt, som det ikke tidligere var almindeligt at træffe fra den Side. Det bør ogsaa bemærkes, at da W. Platzhoff, IK. Rheindorf og Johs. Tiedje paa det tyske Udenrigsministeriums Vegne i 1925 udgav en Aktsamling til Paragraf 5's Historie, der absolut ikke kunde tilfredsstille de Krav, der maatte stilles til en saadan, rejste Prof. Scheel straks Indvending imod den, og sammen med Universitetsselskabets Formand, Dr. Schifferer, foranledigede han, at der blev optaget et Arbejde for at udgive et Supplement, og i 1929 kunde Selskabet ved Fritz Hähnsen udsende endnu 2 store Bind Akter vedrørende Paragraf 5.

For nylig har Prof. Scheel sammen med en af sine Elever, Peter Paulsen, Vestre, udgivet " $Q$ u e llen zur Frage Schleswig-Haithahu im Rahmen der fränkischen, sächsischen und nordischen Beziehungen« (Kiel. 1930), et mønstergyldigt Udvalg af Tekster til Belysning af Hedebys Historie $\mathbf{i}$ det 9. og 10. Aarhundrede, omfattende ikke færre end 244 Kildesteder, hentede fra Runeindskrifter, Aarbøger og Breve, Levnedsskildringer, Krøniker og Sagaer, med mangfoldige Henvisninger til Parallelsteder og til Litteraturbehandlinger, et overordentlig værdifuldt Hjælpemiddel ved Studiet af det saa aktuelle Spørgsmaal, som den kommende Sommers Udgravninger, hvortil Prof. Scheel har skaffet Midler, sikkert vil gøre endnu mere aktuelt. 
Man maa haabe, at Professor Scheel i den kommende Tid vil kunne hellige sig Studiet af Hertugdømmernes Historie, vi vil da sikkert kunne vente værdifulde Arbejder fra hans Haand.

(Fortsættes.) 